\title{
Evolution and effectiveness of HPLC technique for rapid estimation of an antiallergenic agent bilastine
}

\author{
wafaa essa ${ }^{1}$, Amr Beltagi $^{1}$, Ibrahim Lashin $^{1}$, Abla Hathoot ${ }^{1}$, and Magdi abdelazzem ${ }^{1}$ \\ ${ }^{1}$ Affiliation not available
}

May 29, 2020

\begin{abstract}
A new, simple, accurate and specific RP-HPLC stability indicating method for determination of bilastine has been developed and validated. The proposed method has been administrated by C18 BDS Hypersil thermo column (4.6 x $250 \mathrm{~mm}$ i.d), $5 \mu \mathrm{m}$ particle size with a combination of potassium dihydrogen phosphate buffer $\mathrm{pH}$ 6.0: acetonitrile: methanol (50:25:25) as mobile phase at wave length $220 \mathrm{~nm}$. The retention time has been $3.9 \mathrm{~min}$ for bilastine. Calibration plot has been linear over the concentration range $14.4-33.6 \mu \mathrm{g} / \mathrm{ml}$ bilastine with LOD and LOQ of 0.04 and $0.11 \mu \mathrm{g} / \mathrm{ml}$, severally. The technique has been validated for linearity, sensitivity, accuracy, precision and robustness. Percent recoveries have been observed near to a hundred percent with slight change. The validated method has been applied for determination of bilastine in Pharma-bilast(R) tablets. The technique could be appropriate for routine evaluation at laboratories.
\end{abstract}

\section{Hosted file}

bilastine paper.docx available at https://authorea.com/users/327848/articles/455248evolution-and-effectiveness-of-hplc-technique-for-rapid-estimation-of-an-antiallergenicagent-bilastine 